\title{
MODEL PENINGKATAN PARTISIPASI MASYARAKAT DAN PENGUATAN SINERGI DALAM PENGELOLAAN SAMPAH PERKOTAAN *
}

\author{
Bambang Munas Dwiyanto \\ Fakultas Ekonomi, Universitas Diponegoro \\ Kampus UNDIP Tembalang, Jalan Prof. Sudartho, SH, Semarang
}

Diterima 14 Oktober 2011 / Disetujui 5 Nopember 2011

\begin{abstract}
The study aims to find a model of improving a community's role in the management in town area, particularly household rubbish. The early stage of the study was to analyze a management in town area, located at the Sub-District of Sambiroto, District of Tembalang, Semarang City. To analyze the stakeholders, it was necessary to study and discuss (focus group discussion) the management with them for finding an insight to develop the most appropriate model. The approach used to develop a Community-Based Integrated Rubbish Management was a community empowering through improving the stakeholders' role. The tested model took a trial and error as well as two-year observation, at least, with the experiment at different locations. A community-based household rubbish management system with a $3 \mathrm{R}$ principle by separating rubbish could reduce a 70 percent rubbish volume.
\end{abstract}

Keywords: community's role, empowering, rubbish management, stakeholder

\begin{abstract}
Abstrak: Penelitian ini bertujuan untuk menghasilkan model peningkatan partisipasi masyarakat dalam pengelolaan sampah perkotaan, khususnya sampah rumah-tangga. Tahapan penelitian dimulai dengan mengkaji pola pengelolaan sampah perkotaan yang berlaku pada saat ini dengan lokasi percontohan di Kelurahan Sambiroto, Kecamatan Tembalang, Kota Semarang. Untuk mengkaji peran para stakeholder terkait, dilakukan pengkajian dan diskusi (focus group) dengan stakeholders untuk mendapatkan input guna penyusunan model pengelolaan terbaik (best practises) dalam pengelolaan sampah. Pendekatan yang dipakai untuk menyusun model Pengelolaan Sampah Terpadu Berbasis Masyarakat ini adalah pendekatan pemberdayaan masyarakat (community empowering) melalui peningkatan pastisipasi stakeholdersnya. Model yang telah teruji memerlukan trial and error serta memerlukan waktu sekurang-kurangnya 2 tahun pengamatan dengan percobaan di beberapa lokasi yang berbeda.
\end{abstract}

Kata kunci: partisipasi masyarakat, pemberdayaan, pengelolaan sampah, stakeholder

\section{PENDAHULUAN}

Pembangunan berkelanjutan adalah sebagai upaya manusia untuk memperbaiki mutu kehi-

\footnotetext{
Tulisan ini merupakan bagian dari hasil penelitian Hibah Strategis yang dibiayai oleh DP2M-DIKTI melalui program penelitian Multitahun DIPA UNDIP TA. 2009/2010 dengan nomor kontrak No.0363/023-04.2/XIII/2010 tanggal 31 Desember 2009 No.2466/H7.P/KP/2010 tanggal 21 April 2010.
}

dupan dengan tetap berusaha tidak melampaui ekosistem yang mendukung kehidupannya. Dewasa ini masalah pembangunan berkelanjutan telah dijadikan sebagai isu penting yang perlu terus disosialisasikan di tengah masyarakat. Pembangunan berkelanjutan (Emil Salim, 1990) bertujuan untuk meningkatkan kesejahteraan masyarakat, untuk memenuhi kebutuhan dan aspirasi manusia. Pembangunan yang berkelanjutan pada hekekatnya ditujukan untuk mencari pemerataan pembangunan antargene- 
rasi pada masa kini maupun masa mendatang. Menurut KLH (1990) pembangunan (yang pada dasarnya lebih berorientasi ekonomi) dapat diukur keberlanjutannya berdasarkan tiga kriteria yaitu: (1) Tidak ada pemborosan penggunaan sumber daya alam atau depletion of natural resources; (2) Tidak ada polusi dan dampak lingkungan lainnya; (3) Kegiatannya harus dapat meningkatkan useable resources ataupun replaceable resource.

Dewasa ini masalah sampah merupakan salah satu masalah serius dalam lingkungan hidup diseluruh dunia dan kaitannya sangat erat dengan kehidupan manusia sehari-hari. Semua orang tidak bisa terlepas dengan masalah sampah, sebagai pihak yang menghasilkan sampah. Maka boleh dikatakan masalah sampah adalah masalah persepsi masyarakat mengenai sampah.

Untuk mencapai kondisi masyarakat yang hidup sehat dan sejahtera di masa yang akan datang, akan sangat diperlukan adanya lingkungan permukiman yang sehat. Dari aspek persampahan, maka kata sehat akan berarti sebagai kondisi yang akan dapat dicapai bila sampah dapat dikelola secara baik sehingga bersih dari lingkungan permukiman dimana manusia beraktifitas di dalamnya (Permen PU nomor: 21/PRT/M/2006).

Potensi Pengelolaan Sampah Menuju Zero Waste. Pengelolaan Sampah Perkotaan adalah mulai dari produksi sampai berakhirnya suatu proses produksi dapat dihindari terjadi produksi sampah atau diminimalisir terjadinya sampah (Urip Santoso, 2009). Konsep Zero Waste ini salah satunya dengan menerapkan prinsip $3 \mathrm{R}$ (Reduce, Reuse, Recycle). Pemikiran konsep zero waste adalah pendekatan serta penerapan sistem dan teknologi pengolahan sampah perkotaan skala individual dan skala kawasan secara terpadu dengan sasaran untuk dapat mengurangi volume sampah sesedikit mungkin. Konsep 3R adalah merupakan dasar dari berbagai usaha untuk mengurangi limbah sampah dan mengoptimalkan proses produksi sampah (Suryanto dkk., 2005).

Diselaraskan dengan pengelolaan Sampah Berbasis Masyarakat (Community Based Solid Waste Management/CBSWM) adalah suatu pendekatan pengelolaan sampah yang didasarkan pada kebutuhan dan permintaan masyarakat, direncanakan, dilaksanakan, dikontrol, dan di evaluasi bersama masyarakat (Environmental Services Program (ESP) DKI, 2006). Berbasis masyarakat karena produsen utama adalah masyarakat sehingga, masyarakat harus bertanggung jawab terhadap sampah yang masyarakat produksi. CBSWM ini tujuannya adalah kemandirian masyarakat dalam mempertahankan kebersihan lingkungan melalui pengelolaan sampah yang ramah lingkungan

Rumusan Masalah. Kota akan selalu berhubungan erat dengan perkembangan lahan baik dalam kota itu sendiri maupun pada daerah yang berbatasan atau daerah sekitarnya. Selain itu lahan juga berhubungan erat dengan manusia dan lingkungan (Setyawati, D., 2008). Penjelasan tentang teori kependudukan menyatakan bahwa populasi seharusnya dalam titik keseimbangan di mana lingkungan dapat mendukung dan batas di antara titik keseimbangan tersebut merupakan daya dukung dari lingkungan (Kormondy, EJ., 1969). Oleh karena itu perkembangan dan pertumbuhan kota yang baik merupakan kota yang dapat menyeimbangkan antara kondisi lingkungan dengan kepadatan penduduk yang akan ditampung dalam kota tersebut

Kota Semarang sebagai ibukota Provinsi Jawa Tengah memiliki jumlah penduduk sebesar 1.434.025 jiwa pada tahun 2006 (BPS Semarang, 2006), dengan besarnya jumlah penduduk tersebut maka jumlah timbulan sampah juga sangat besar. Berdasarkan penelitian Sobirin, timbunan sampah tiap harinya sampai mencapai $4.725 \mathrm{~m}^{3}$, yang terangkut sekitar $4.150 \mathrm{~m}^{3}$, yang belum terlayani sekitar $565 \mathrm{~m}^{3}$ setiap harinya. Sedangkan sampah yang terbuang di TPA Jatibarang tiap harinya sekitar $2.500 \mathrm{~m}^{3}$ atau sekitar 600 ton (Sobirin, Mei 2008). Dari jumlah timbulan sampah tersebut hanya 65 persen yang dapat ditampung di TPA sedangkan sisanya (35 persen) dibuang ke kali, ditimbun atau dibakar oleh masyarakat (Kompas 09 April 2008).

Sistem pengelolaan sampah di Kota Semarang dapat dikatakan masih tergolong menggunakan konsep tradisional yang menganut konsep kumpul, angkut, dan buang. Sistem ini masih terus digunakan karena masyarakat belum 
mengetahui cara pengelolaan sampah dengan baik. Dimulai dari cara mengurangi timbunan sampah domestik (reduce), menggunakan kembali sampah domestik yang masih layak digunakan (reuse) dan mendaur ulang sampah domestik (recycle) sehingga sampah tersebut dapat bernilai ekonomi.

Perencanaan Pengelolaan Sampah Rumah Tangga Berbasis Masyarakat. Perencanaan merupakan suatu proses yang mempersiapkan seperangkat keputusan untuk melakukan tindakan di masa depan. Tahap perencanaan merupakan tahapan awal dalam proses pelaksanaan program pembangunan pengelolaan sampah. Hal ini dimaksudkan bahwa perencanaan akan memberikan arah, langkah atau pedoman dalam proses pembangunan dimaksud. Pada tahapan ini akan ditelusuri aktivitas atau kegiatan yang dilakukan masyarakat, dimulai dari keterlibatan mereka dalam menyusun rencana program yang diaktualisasikan melalui keaktifannya pada setiap rapat dan inisiatif diadakannya rapat, dan keterlibatan dalam memberikan pendapat, tanggapan masyarakat serta pengembangan terhadap upaya pengelolaan sampah, sampai dengan keterlibatan mereka dalam pengambilan keputusan terhadap program yang direncanakan. Melalui interaksi dan komunikasi, perencanaan bersama dengan masyarakat membantu mengidentifikasi masalah, merumuskan tujuan, memahami situasi dan mengidentifikasi solusi bagaimana memecahkan masalah masalah yang dimaksud. Dalam konteks ini perencanaan adalah aktivitas moral, perencanaan merupakan komunikator yang menggunakan bahasa sederhana dalam pekerjaannya agar membuat logik dari perilaku manusia. Kunci dari gagasan perencanaan dan pembelajaran sosial adalah evolusi dari desentralisasi yang membantu orang-orang untuk memperoleh akses yang lebih dalam pengambilan keputusan yang mempengaruhi kehidupan mereka (Hadi, 2001:19).

Menurut Alexander Abe,(2001:98), tahapan perencanaan yang harus dilalui yaitu: (1) Tahap pembuatan kesepakatan awal, dimaksudkan untuk menetapkan wilayah dari perencanaan, termasuk prosedur teknis yang akan diambil dalam proses perencanaan; (2) Perumusan ma- salah adalah tahap lanjut dari hasil penyelidikan. Data atau informasi yang dikumpulkan diolah sedemkian rupa sehingga diperoleh gambaran yang lebih lengkap, utuh dan mendalam; dan (3) Identifikasi daya dukung yang dimaksud dalam hal ini, daya dukung tidak harus segera diartikan dengan dana kongkrit (money, atau uang), melainkan keseluruhan aspek yang bisa memungkinkan terselenggaranya aktivitas dalam mencapai tujuan dan target yang telah ditetapkan. Daya dukung akan sangat tergantung pada persoalan yang dihadapi, tujuan yang hendak dicapai, aktivitas yang akan datang. Pengelolaan sampah tentu tidak saja dapat ditopang dengan gerakan yang hanya ditanamkan pada masyarakat. Hal tersebut ditanamkan pada pemerintah, yang juga bertanggung jawab terhadap ersoalan pengolahan sampah ini.

Secara umum, pekerjaan perencanaan teknis pengelolaan sampah terpadu 3R (Reuse, Reduce, Recycle) yaitu:

1. Tahap Persiapan. Tahap persiapan pelaksanaan pengelolaan sampah berbasis masyarakat adalah melakukan persiapan dengan melakukan tindakan peningkatan pemahaman masyarakat terhadap konsep dasar program pengelolaan sampah berbasis masyarakat, terutama teknologi komposting di tingkat masyarakat. Dinas Kebersihan Kota Semarang menyusun metode dan pendekatan untuk pelaksanaan pekerjaan yang meliputi antara lain; menentukan pemilihan lokasi, menentukan pengorganisasian dan pemerdayaan masyarakat, serta pengadaan sarana dan prasarana pengelolaan sampah berbasis masyarakat.

2. Tahap Pemilihan Lokasi. Tahap pemilihan lokasi di sini merupakan awal dimulainya tahap pengumpulan data calon lokasi yang akan dipilih untuk melaksanakan program pengelolaan sampah rumah tangga berbasis masyarakat. Data data tersebut dapat diperoleh dari hasil kajian studi Rencana Tata Ruang Wilayah (RTRW) dan Rencana Retail Tata Ruang Kota (RDTRK)

3. Tahap Perencanaan Teknis. Tahap perencanaan teknis adalah tahap penyusunan dokumen kerja serta melakukan pengadaan peralatan pengelolaan sampah. Peralatan prasarana 
dan sarana persampahan 3R (Reuse, Reduce, Recycle) yang meliputi penentuan jenis dan jumlah peralatan, baik untuk pemilahan jenis sampah, pewadahan dan pengangkutan dan alat pengolahan sampah untuk menjadi kompos, termasuk mengidentifikasi kebutuhan tempat untuk pengolahan sampah terpadu TPS (Tempat Penampungan Sementara).

4. Tahap Pengorganisasian Masyarakat. Pengorganisasian tentang pemberdayaan masyarakat dan stakeholder menjadi fasilitator terhadap kegiatan di tingkat komunitas/masyarakat di kawasan lokasi terpilih. Tahap ini dibagi menjadi 4 kegiatan: melakukan identifikasi lokasi terpilih, melakukan sosialisasi pada masyarakat dengan cara memperkenalkan program pengelolaan sampah, pembentukan organisasi, melakukan pelatihan pengelolaan sampah terpadu.

Kegiatan penyusunan program sampah 3R (reuse, reduce, recycle) adalah proses penyusunan rencana pengelolaan sampah terpadu berbasis masyarakat dengan pola 3R adalah: membuat identifikasi permasalahan dan menentukan rumusan permasalahan serta menentukan kebutuhan yang dilakukan dengan metode penyerapan aspirasi masyarakat dan melakukan survei kampung sendiri dan menyusun analisis permasalahan untuk menentukan skala prioritas kebutuhan serta menentukan potensi sumber daya setempat.

Kegiatan menyusun indentifikasi kebutuhan peralatan prasarana dan sarana persampahan 3R (Reuse, Reduce, Recycle) yaitu menentukan jenis dan jumlah peralatan yang dibutuhkan dalam pengelolaan sampah rumah tangga berbasis masyarakat, pewadahan, pengangkutan dan alat pengolahan sampah untuk menjadi kompos.

5. Tahap Evaluasi dan Uji Coba Pelaksanaan Pengelolaan Sampah 3R. Tahap evaluasi ini merupakan rangkuman dari keseluruhan hasil program pengelolaan sampah rumah tangga berbasis masyarakat. Kegiatan evaluasi ini dilakukan secara bertahap, disesuaikan dengan kemajuan kegiatan yang telah dilakukan oleh masyarakat, dan dilakukan pengontrolan secara intensif serta bebagai upaya untuk menyiapkan kemandirian masyarakat.

Pengelolaan Sampah dengan Konsep 3R. Menurut Departemen Pekerjaan Umum Kota
Semarang (2008), pengertian pengelolaan sampah 3R secara umum adalah upaya pengurangan pembuangan sampah, melalui program menggunakan kembali (Reuse), mengurangi (Reduce), dan mendaur ulang (Recycle).

(1) Reuse (menggunakan kembali) yaitu penggunaan kembali sampah secara langsung,baik untuk fungsi yang sama maupun fungsi lain.

(2) Reduce (mengurangi) yaitu mengurangi segala sesuatu yang menyebabkan timbulnya sampah.

(3) Recycle (mendaur ulang) yaitu memanfaatkan kembali sampah setelah mengalami proses pengolahan. Mengurangi sampah dari sumber timbulan, di perlukan upaya untuk mengurangi sampah mulai dari hulu sampai hilir, upayaupaya yang dapat dilakukan dalam mengurangi sampah dari sumber sampah (dari hulu ) adalah menerapkan prinsip 3R sesuai petunjuk teknis nomor CT/Rc-TC/001/98 atau pendekatan prinsip produksi sampah sebagaimana dikemukakan oleh Winarno dkk (1995).

Tindakan yang bisa dilakukan untuk setiap sumber sampah adalah sebagai berikut:

(1) Rumah Tangga, Tindakan yang bisa dilakukan adalah:

(a) Mengurangi (Reduce), melalui tindakan: (i) Menghindari pemakaian dan pembelian produk yang menghasilkan sampah dalam jumlah besar; (ii) Menggunakan produk yang bisa di isi ulang, misalnya penggunan lahan pencuci yang menggunakan wadah isi ulang; (iii) Mengurangi penggunaan bahan sekali pakai, misalnya penggunaan tissu dapat dikurangi, menggantinya dengan serbet atau sapu tangan.

(b) Menggunakan Kembali (Reuse), melalui tindakan: (i) Gunakan kembali wadah/kemasan untuk fungsi yang sama atau fungsi lainnya, misalnya penggunaan botol bekas untuk wadah minyak goreng hasil home industry minyak kelapa atau wadah untuk madu lebah; (ii) Gunakan wadah atau kantong yang dapat digunakan berulang ulang misalnya, wadah untuk belanja kebutuhan pokok yang terbuat dari bahan yang tahan lama sehingga dapat digunakan dalam waktu yang lama.

(c) Daur ulang (Recycle), melalui tindakan: (i) Pilih produk atau kemasan yang dapat di daur ulang dan mudah terurai; (ii) Lakukan penggu- 
naan sampah organik menjadi kompos dengan berbagai cara yang telah ada atau memanfaatkan sesuai kreaktifitas masing-masing; (iii) Lakukan penanganan untuk sampah anorganik menjadi barang yang bermanfaat.

(2) Fasilitas Umum (perkantoran, sekolah)

(a) Mengurangi (Reduce) produksi sampah dengan cara: (i) Penggunaan kedua sisi kertas dan spasi yang tepat untuk penulisan dan foto copy; (ii) Penggunaan alat tulis yang bisa di isi kembali; (iii) Sediakan jaringan informasi dengan komputer (tanpa kertas); (iv) Gunakan produk yang dapat di isi ulang; (v) Hindari bahan yang sekali pakai; (vi) Hindari penggunaan bahan dari plastik dalam penjilidan laporan-laporan;

(b) Menggunakan kembali (reuse), melalui tindakan: (i) Gunakan alat kantor yang bisa digunakan berulang kali; (ii) Gunakan alat-alat penyimpanan elektronik yang dapat diapus dan ditulis kembali.

(3) Daerah Komersil

(a) Mengurangi (reduce), melalui tindakan: (i) Memberikan intensif oleh produsen bagi pembeli yang mengembalikan kemasan yang dapat digunakan kembali; (ii) Memberikan kemasan/ pembungkus hanya kepada produk yang benar benar memerlukannya; (iii) Sediakan produk yang kemasannya tidak menghasilkan sampah dalam jumlah besar; (iv) Sediakan pembungkus/kemasan yang mudah terurai.

(b) Menggunakan Kembali (reuse): (i) Gunakan sampah yang masih dapat di manfaatkan untuk produk lain; (ii) Sediakan perlengkapan untuk pengisian kembali produk umum isi ulang (minyak, minuman).

\section{METODE PENELITIAN}

\section{Pelaksanaan Pengelolaan Sampah Rumah Tangga Berbasis Masyarakat}

Pasal 16 Undang-undang Lingkungan Hidup No.23 Tahun 1997, yaitu berbunyi tanggung jawab pengelolaan lingkungan ada pada masyarakat sebagai produsen timbulan limbah sejalan dengan hal tersebut, masyarakat sebagai produsen timbulan sampah diharapkan terlibat secara total dalam lima subsistem pengelolaan sampah, yang meliputi 1) subsistem kelembagaan, 2) subsistem teknis operasional, 3) subsistem finansial, 4) subsistem hukum dan peraturan serta 5) subsistem peran serta masyarakat.

Menurut Syafrudin (2004), salah satu alternatif yang bisa dilakukan adalah melaksanakan program pengelolaan sampah berbasis masyarakat, seperti minimasi limbah dan melaksanakan 5 R (Reuse, Recycling, Recovery, Replacing, dan Refilling). Kedua program tersebut bisa dimulai dari sumber timbulan sampah hingga kelokasi TPA. Seluruh subsistem di dalam sistem harus dipandang sebagai suatu sistem yang memerlukan keterpaduan dalam pelaksanaannya. Sistem pengelolaan sampah terpadu (Integrated Solid Waste management) didefinisikan sebagai pemilihan dan penerapan program teknologi dan manajemen untuk mencapai sistem yang tinggi, dengan hirarki sebagai berikut (Syafrudin, 2004 ):

(1) Source Reduction, yaitu proses minimalis sampah di sumber dalam hal kuantitas timbulan dan kualitas timbulan sampah, terutama reduksi sampah berbahaya.

(2) Recyclling, yaitu proses daur ulang yang berfungsi untuk mereduksi kebutuhan sumberdaya dan reduksi kuantitas sampah ke TPA.

(3) Waste Transformation, yaitu proses perubahan fisik, kimia dan biologis perubahan sampah. Dimana ketiga komponen itu akan menentukan: (a) perubahan tingkat efesiensi yang diperlukan di dalam sistem pengelolaan; (b) Perlunya proses reduce, reuse, dan recycle sampah; (c) Proses yang dapat menghasilkan barang lain yang bermanfaat seperti pengomposan.

(4) Landfilling, sebagai akhir dari suatu pengelolaan sampah yang tidak dapat dimanfaatkan kembali.

Pemilihan dan penerapan teknologi dalam kontek ini tentunya dilakukan sehingga terpilih teknologi tepat guna. Di dalam operasional sistem pengelolaan sampah, pendekatan yang tepat adalah pendekatan sistem pemanfaatan terpadu (Integrated Material Recovery-IMR). Pada masyarakat yang masih mengandalkan TPA sebagai akhir pengelolaan limbahnya, strategi pendekatan IMR ini tepat untuk diterapkan. Kesadaran masyarakat untuk menerapkan konsep ini akan memicu tumbuhnya pengelolaan 
sampah berbasis masyarakat di samping kegiatan yang berusaha untuk meminimasi sampah. Mengingat konsep IMR pada dasarnya adalah memanfaatkan kembali sampah yang masih berpotensi untuk didaur ulang, disetiap langkah operasi yaitu mulai dari pewadahan, pengumpulan, pengangkutan dan pembuangan akhir. Sistem IMR akan meningkatkan perolehan berbagai bahan yang bernilai ekonomi dan dapat dipasarkan, bukan menghambat kemampuan yang ada.

\section{Partisipasi Masyarakat}

Definisi partisipasi dalam kaitan dengan pembangunan sering ditemukan dalam berbagai kegiatan program pembangunan sebagai sarana untuk memperkuat relevansi, kualitas dan kesinambungan suatu program pembangunan. Partisipasi terkadang masih menjadi sebuah kata yang memiliki arti yang berbeda bagi setiap orang. Sebagaimana dikutip new economics foundation, sekelompok tim dari Bank Dunia mendefinisikan partisipasi sebagai "proses dimana para pemilik kepentingan (stakeholders) mempengaruhi dan berbagi pengawasan atas inisiatif dan keputusan pembangunan serta sumber daya yang berdampak pada mereka" (Bank dunia, 1995). Dari sudut pandang ini, partisipasi dapat dilihat pada tataran konsultasi atau pengambilan keputusan dalam semua tahapan siklus proyek, dari evaluasi kebutuhan sampai penilaian, implementasi, pemantauan dan evaluasi.

Partisipasi masyarakat secara sederhana diartikan dengan keikutsertaan masyarakat dalam suatu kegiatan baik itu pada tahap persiapan, perencanaan, design, pelaksanaan maupun monitoring dan evaluasi. Keikutsertaan masyarakat ini dapat dibagi atas beberapa tingkatan sesuai kedalaman keterlibatannya. Ada kegiatan yang hanya mengikutsertakan masyarakat sebagai pendengar dalam suatu proses perencanaan, ada juga kegiatan yang meminta masyarakat memberikan masukan (konsultasi dengan

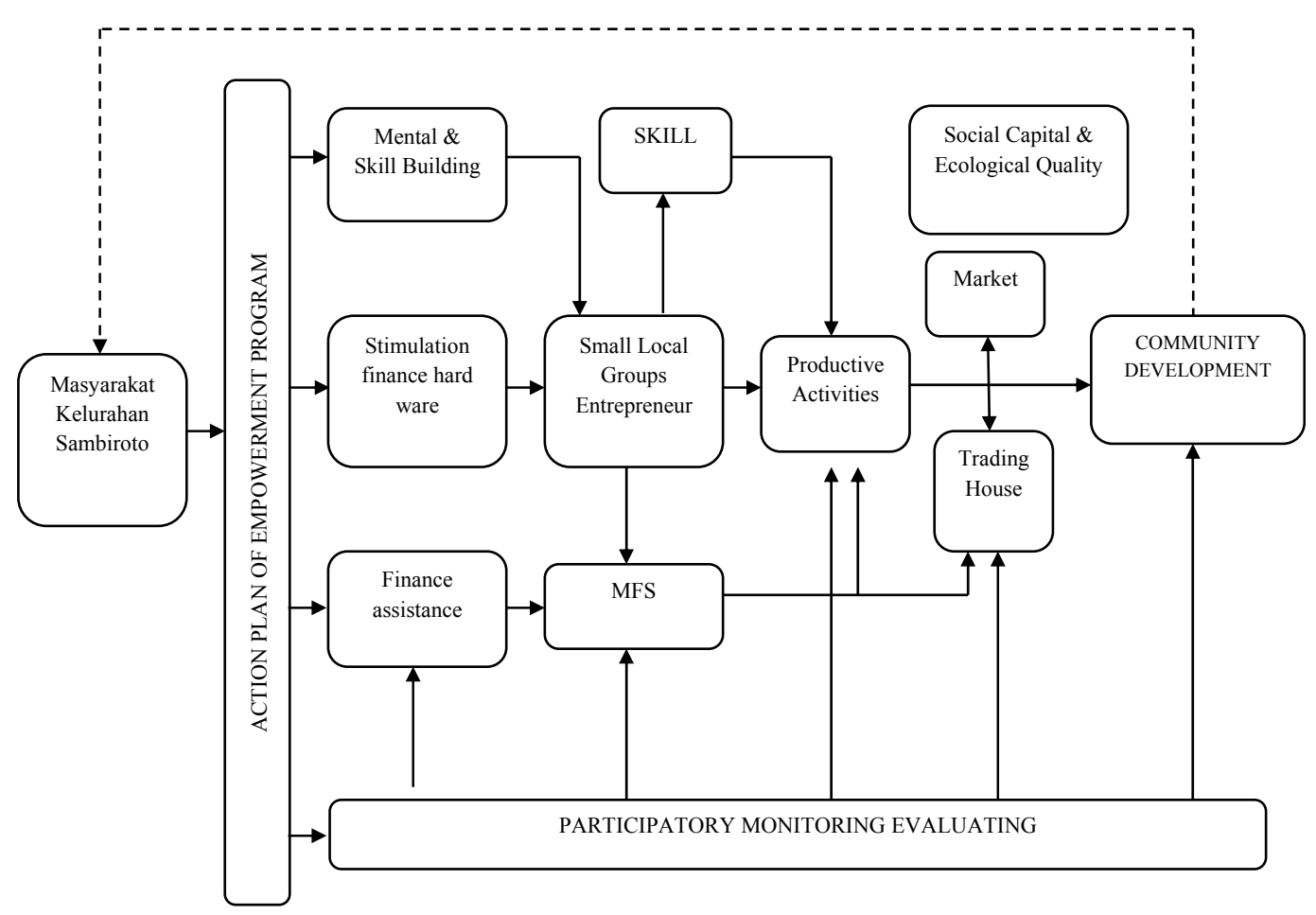

Sumber: Community development 2007 dengan modifikasi

Gambar 1. Kerangka Pendekatan Partisipasi Masyarakat 
masyarakat) dan ada juga yang bahkan meminta masyarakat untuk memutuskan sendiri kegiatan apa yang akan dilakukan, bagaimana kegiatan tersebut diorganisir

Kerangka Pendekatan Partisipasi yang digunakan dalam pemetaan kemitraan melibatkan partisipasi semua pihak dan yang paling sentral adalah pihak masyarakat lokal itu sendiri. Partisipan inilah yang merancang berbagai perencanaan tindakan strategis seperti pengembangan mental dan keterampilan, stimulasi dana, dan sarana serta pendampingan lembaga keuangan melalui sistem pelayanan keuangan mikro, serta evaluasi dan monitoring. Semua kegiatan diarahkan kepada kelompok masyarakat Kelurahan Sambiroto agar mereka memiliki komitmen dan keterampilan, serta akses sarana dan permodalan yang mendukung aktivitas usaha produktif.

Hasil produk diharapkan dapat langsung diakses oleh pasar ataupun melalui sebuah institusi yang menampung hasil produk mereka yang dikenal dengan trading house. Dalam seluruh rangkaian kegiatan dari mulai penguatan mental dan keterampilan, pelayanan pendampingan permodalan, dan usaha produktif hingga pemasaran dilakukan monitoring dan evaluasi secara partisipatif dengan tujuan ditemukan keberhasilan dan kekurangan implementasi program kemitraan ini dan dicarikan jalan keluar sehingga program ini bisa berhasil. Capaian dari serangkaian kegiatan kemitraan ini tidak lain adalah kesejahteraan masyarakat, yang pada akhirnya akan memberikan feed back bagi terciptanya model sosial budaya dan lingkungan yang kondusif juga peningkatan citra positif para partisipan yang terlibat dalam program ini. Kerja logis ini akan terus berulang sebagai gerakan pemberdayaan dalam jangka panjang yang diharapkan bisa menciptakan keberdayaan dan kemandirian masyarakat.

\section{Pemberdayaan}

Pengertian pemberdayaan masyarakat sebenarnya mengacu pada kata empowerment, yaitu sebagai upaya untuk mengaktualisasikan potensi yang sudah dimiliki masyarakat. Dalam pengembangan masyarakat nelayan penekanan berada pada pentingnya masyarakat lokal yang mandiri, sebagai suatu sistem yang mengorganisir diri mereka sendiri. Pendekatan pemberdayaan masyarakat yang demikian tentunya diharapkan memberikan peranan kepada individu bukan hanya sebagai objek, tetapi sebagai pelaku (aktor) yang menentukan kelompok mereka Pendekatan pemberdayaan masyarakat yang berpusat pada manusia ini kemudian melandasi wawasan pengelolaan sumber daya lokal, yang merupakan mekanisme perencanaan people-centered development yang menekankan pada teknologi pembelajaran sosial (social learning) dan strategi perumusan program. Adapun tujuan yang ingin dicapai adalah untuk meningkatkan kemampuan masyarakat dalam mengaktualisasikan dirinya (empowerment) (Moelyarto, 1996).

Menurut Ginanjar Kartasasmita (1996) dalam Surochiem (2001), pemberdayaan masyarakat merupakan suatu konsep pembangunan ekonomi yang merangkum nilai-nilai sosial. Konsep ini mencerminkan paradigma baru pembangunan yakni people centered, participatory, empowering, and sustainable. Konsep ini tidak hanya semata-mata memenuhi kebutuhan dasar (basic needs) dan mencegah proses kemiskinan lebih lanjut (safety net) dimana upaya yang dilakukan akan diarahkan langsung kepada akar persoalannya, yaitu meningkatkan kemampuan masyarakat. Bagian yang tertinggal dalam masyarakat harus ditingkatkan kemampuannya dengan mengembangkan dan mendinamisasikan potensinya atau dengan kata lain memberdayakannya. Dengan demikian rakyat dengan lingkungannya mampu secara partisipatif menghasilkan dan menumbuhkan nilai tambah ekonomis. Rakyat miskin atau yang berada pada posisi belum termanfaatkan secara penuh potensinya akan meningkat bukan hanya ekonominya tetapi juga harkat, martabat, rasa percaya diri dan harga dirinya. Dengan demikian, dapatlah diartikan pemberdayaan tidak saja menumbuhkan dan mengembangkan nilai tambah ekonomis, tetapi juga nilai tambah sosial dan nilai tambah budaya.

Dari uraian di atas dapat ditarik kesimpulan bahwa keberdayaan masyarakat terletak pada proses pengambilan keputusan sendiri untuk mengembangkan pilihan-pilihan adapta- 
si terhadap perubahan lingkungan dan sosial. Oleh sebab itu, pemahaman mengenai proses adaptasi masyarakat pesisir terhadap lingkungannya merupakan informasi penting dalam pembangunan yang berorientasi pada manusia (people-centered development), yang melandasi wawasan pengelolaan sumber daya lokal (community-based resource management). Pentingnya memperhatikan aspek strategi adaptasi nelayan dan pengolah ikan dalam kegiatan pemberdayaan tersebut adalah karena strategi adaptasi yang dikembangkan memungkinkan mereka mengatur daya tahan (resiliance) terhadap persoalan-persoalan spesifik di lingkungan pesisir yang dihadapi, seperti: fluktuasi, ketidakpastian hasil tangkapan maupun hasil olahan, atau menurunnya sumber daya perikanan.

\section{Lokasi Penelitian}

Lokasi penelitian terletak di wilayah RW 03 dan RW 06 kelurahan Sambiroto Kecamatan Tembalang Kota Semarang. Pemilihan lokasi didasarkan pada pertimbangan bahwa: (1) Lokasi ini telah memiliki akses pelayanan sampah dari tingkat kota Semarang; (2) Terdapat variasi tingkat pendidikan, pengetahuan dan sosial ekonomi masyarakat yang memungkinkan adanya variasi tingkat partisipasi dalam mengikuti kegiatan pengelolaan sampah berbasis masyarakat ini.

\section{Road Map Penelitian}

Road map penelitian ini adalah Strategi Pemberdayaan Masyarakat (Gambar 2 dalam Lampiran) dan Diagram Pelaksanaan Peningkatan Partisipasi Masyarakat dan Penguatan Sinergi dalam Pengelolaan Sampah Perkotaan di Kelurahan Sambiroto, Kecamatan Tembalang, Kota Semarang (Gambar 3 dalam Lampiran).

\section{HASIL DAN PEMBAHASAN}

Tingkat Partisipasi Masyarakat dalam Pengelolaan Sampah Rumah Tangga Berbasis Masyarakat

Terkait dengan pelaksanaan kegiatan pengelolaan sampah perkotaan di Kelurahan Sambi- roto, tahapan kegiatan telah dirancang untuk semaksimal mungkin melibatkan masyarakat. Dengan demikian, kegiatan ini pada akhirnya dapat menjadi bagian dari kegiatan rutin masyarakat dalam pengelolaan sampah dan berkesinambungan (sustainable). Tingkat keikutsertaan masyarakat dalam serial kegiatan pengelolaan sampah perkotaan di Sambiroto dapat diuraikan sebagai berikut:

Partisipasi dalam Identifikasi Masalah. Kegiatan identifikasi masalah merupakan kegiatan awal yang dilakukan tim peneliti dalam menyusun langkahg-langkah detail pelaksanaan pengelolaan sampah perkotaan di kelurahan sambiroto. Secara umum, identifikasi masalah dilakukan dalam bentuk diskusi terbatas dan terarah (Focus Group Discussion: FGD) dengan kelompok masyarakat di tingkat RT melalui forum-forum pertemuan baik untuk para ibu maupun para bapak-bapak. Selain melalui forum FGD, identifikasi masalah dilakukan juga melalui wawancara mendalam (indepth interview) dengan beberapa tokoh masyarakat baik formal maupun nonformal, para ibu rumah tangga dan petugas sampah. Beberapa data dan informasi terkait pengelolaan sampah di Kelurahan Sambiroto pada umumnya dan RW 06 dan 03 pada khususnya adalah: (1) Sistem pengelolaan sampah di Kelurahan Sambiroto diserahkan sepenuhnya kepada masing-masing RT/RW; (2) RT/RW melakukan perjanjian kerjasama dengan petugas sampah untuk mengangkut sampah dari rumah tangga ke tempat pembuangan sampah sementara (TPS) terdekat yang ada.

Partisipasi dalam Sosialisasi. Kegiatan sosialisasi berkaitan dengan upaya meningkatkan pengetahuan dan pemahaman masyarakat tentang pengelolaan sampah perkotaan, kendala dan hambatan serta potensi-potensi yang dapat dikembangkan guna peningkatan kesejahteraan masyarakat. Kegiatan sosialiasi juga bertujuan mendapatkan dukungan masyarakat secara umum tentang pentingnya pengelolaan sampah secara berkelanjutan.

Partisipasi masyarakat dalam kegiatan sosialisasi berkaitan dengan pemberian inputinput tentang pengelolaan kegiatan lebih lanjut. Dalam setiap forum sosialisasi, masyarakat diminta memberikan masukan terkait rencana 
tindak lanjut apa yang harus dilakukan selanjutnya, siapa yang akan melakukan, bagaimana, kapan dan dimana kegiatan tersebut akan diserlenggarakan. Salah satu output kegiatan sosialisasi adalah kesepakatan rencana kegiatan tindak lanjut (RKTL) yang menjadi keputusan dari forum. Pada aspek ini, partisipasi masyarakat tinggi, khususnya terkait otonomi masyarakat dalam pengambilan keputusan tentang RKTL. Salah satu contoh adalah penundaan warga RW 01 terhadap kegitan ini. Para wakil warga RW 01 memutuskan untuk tidak melanjutkan kegiatan ini sebelum lebaran 2010 akibat kesibukan para ibu rumah tangga. Dengan demikian kegiatan ini untuk sementara tidak dapat digulirkan pada warga RW 01 Kelurahan Sambiroto.

Partisipasi dalam Pelatihan. Kegiatan pelatihan berkaitan dengan upaya peningkatan pengetahuan, sikap dan ketrampilan masyarakat dalam pengelolaan sampah perkotaan. Kegiatan pelatihan antara lain pelatihan daur ulang sampah unorganik; pelatihan pembuatan kompos dari sampah organik; pelatihan pemilahan sampah unorganik. untuk mengatasi hambatan tersebut. Kegiatan ujicoba juga bertujuan untuk membuktikan bahwa rencana kegiatan pengelolaan sampah perkotaan ini bukan sebatas himbauan dalam rangka sosialisasi suatu kegiatan, tetapi juga dibuktikan melalui aksi nyata antara warga masyarakat dengan tim peneliti.

Kegiatan ujicoba ini dilakukan dalam dua bentuk yakni kegiatan pengolahan sampah organik dan unorganik. Untuk sampah organik, ujicoba yang dilakukan dalam bentuk pembuatan kompos dengan menggunakan keranjang kompos skala rumah tangga. Sedangkan untuk sampah unorganik, ujicoba dilakukan dalam bentuk pengumpulan dan pemilahan sampahsampah unorganik secara terpadu dan tidak dibuang ke tempat pembuangan sementara. Sedangkan kegiatan monitoring berkaitan dengan pemantauan pelaksanaan kegiatan ujicoba penanganan sampah organik.

Partisipasi masyarakat selama kegiatan ujicoba ini berkaitan dengan beberapa hal yakni: 1) penyiapan keranjang kompos, 2) Pelaksanaan ujicoba dan 3) pemantauan pelaksanaan ujicoba. Dalam penyiapan keranjang kompos, 
ujicoba. Monitoring di RW 03 dilakukan tim monitor yang terdiri dari ibu RW dan para ibu RT (empat orang). Kelima orang ini bersama tim peneliti melakukan kunjungan dari rumah ke rumah untuk memeriksa, mengamati penanganan sampah organik dengan keranjang kompos. Selain memeriksa teknis pembuatan kompos; tim monitor batan yang ditemui st perbaikan. Monitorin ketua RW bersama tim

\section{Partisipasi dalam} sanaan kegiatan merı masyarakat tentang sampah yang menggu ce, Reuse, dan Recyc kegiatan; pelaksanaan sil kesepakatan wargc dan mampu melakul secara mandiri dengi Kemandirian masyara lam kegiatan pelaksan organisasian, pendana an. Pengorganisasian struktur dan mechan di tingkat masyarakat anggota masyarakat pah tersebut. Kemanı dengan penggalian su alokasian dan pemanf jawaban penggunaan

lahan sampah dalam

Tabel 6. Indikator Ta Pemberdaya

\begin{tabular}{lr}
\hline & Indi \\
\hline & $\begin{array}{l}\text { Lingkung } \\
\text { bersih da: }\end{array}$ \\
& $\begin{array}{l}\text { Perubaha } \\
\text { Public Sector } \\
\text { Health }\end{array}$
\end{tabular}

Terciptanya sistem pengelolaan sampah berbasis masyarakat

Health teknis pengelolaan sampah berkaitan dengan pengetahuan dan keterampilan menyerap teknologi yang baru diperkenalkan dalam pengelolaan sampah tersebut; baik itu sampah organik maupun sampah unorganik.

Partisipasi masyarakat dalam tahap pelaksanaan kegiatan telah ditunjukkan warga di RT 


\begin{tabular}{|c|c|c|c|}
\hline & Indikator & RW 06 & RW 03 \\
\hline \multirow{3}{*}{ Psikologis } & $\begin{array}{l}\text { Mengurangi beban } \\
\text { pemerintah } \\
\text { mengelola sampah }\end{array}$ & $\begin{array}{l}\text { “...RW } 06 \text { tidak lagi menyisakan } \\
\text { sampah untuk dibuang ke } \\
\text { tempat pembuangan akhir } \\
\text { semua sampah diolah sendiri } \\
\text { oleh masyarakat..." (responden ) }\end{array}$ & $\begin{array}{l}\text { “...memang RW } 03 \text { telah mengurai } \\
\text { volume sampah yang dibuang ke } \\
\text { tempat pembuangan akhir..." } \\
\text { (responden) }\end{array}$ \\
\hline & Kepuasan batin & $\begin{array}{l}\text { “...tumbuh kepuasan mengelola } \\
\text { sampah sejak dari rumah tangga } \\
\text { secara konsekuen..." (responden } \\
\text { ) }\end{array}$ & $\begin{array}{l}\text { “...kami puas dan senang karena telah } \\
\text { berhasil mengelola sampah..." } \\
\text { (responden ) }\end{array}$ \\
\hline & $\begin{array}{l}\text { Peningkatan } \\
\text { kualitas hidup }\end{array}$ & $\begin{array}{l}\text { "...masyarakat dapat } \\
\text { menjalankan kehidupannya } \\
\text { secara berkualitas karena berada } \\
\text { di lingkungan yang sehat..." } \\
\text { (responden ) }\end{array}$ & $\begin{array}{l}\text { “...lingkungan rumah warga semakin } \\
\text { bersih, indah, dan asri. Tanaman- } \\
\text { tanaman semakin subur karena pupuk } \\
\text { cair dari sampah..." (responden ) }\end{array}$ \\
\hline \multirow[t]{4}{*}{$\begin{array}{l}\text { Sosial } \\
\text { Ekonomi }\end{array}$} & $\begin{array}{l}\text { Keringanan biaya } \\
\text { retribusi }\end{array}$ & $\begin{array}{l}\text { “...di tempat lain, dalam setiap } \\
\text { bulannya pasti dipungut biaya } \\
\text { Rp } 3.000 \text { sampai Rp } 10.000 \text { maka } \\
\text { warga justru dapat } \\
\text { menghemat..." }\end{array}$ & $\begin{array}{l}\text { “...warga di sini sekarang lebih ringan } \\
\text { beban retribusinya, dahulu } 1 \mathrm{KK} \text { bisa } \\
\text { membayar Rp } 5.000-10.000 \text { sekarang } \\
\text { tinggal membayar sekitar } 3.000 \\
\text { (responden) }\end{array}$ \\
\hline & $\begin{array}{l}\text { Membuka } \\
\text { lapangan kerja }\end{array}$ & $\begin{array}{l}\text { (1) Upah angkut sampah/ } \\
\text { bulannya/ orang antara 25.000- } \\
50.000 \text { tergantung luas wilayah; } \\
\text { (2) Upah sortir dan } \\
\text { pengepakan/ orang/hari Rp } \\
\text { 15.000; (3) Tas kerajinan dari } \\
\text { sampah berbahan alumunium } \\
\text { foil dibuat oleh ibu-ibu dan } \\
\text { dijual dengan harga Rp 5.000- } \\
75.000\end{array}$ & $\begin{array}{l}\text { Tas kerajinan dari sampah berbahan } \\
\text { alumunium foil dibuat oleh ibu-ibu dan } \\
\text { dijual dengan harga } \operatorname{Rp} 5.000-75.000\end{array}$ \\
\hline & $\begin{array}{l}\text { Pengurangan } \\
\text { pengeluaran } \\
\text { pokok untuk } \\
\text { pupuk }\end{array}$ & $\begin{array}{l}\text { "...efisiensi pengeluaran rumah } \\
\text { tangga mengingat kompos yang } \\
\text { dihasilkan di setiap rumah } \\
\text { dapat dimanfaatkan untuk } \\
\text { pupuk bagi tanaman sawah } \\
\text { maupun pekarangan..." }\end{array}$ & $\begin{array}{l}\text { “..warga tidak perlu lagi membeli } \\
\text { pupuk untuk memupuk tanamn hias } \\
\text { mereka...” (responden) }\end{array}$ \\
\hline & $\begin{array}{l}\text { Penambahan } \\
\text { inventaris RW }\end{array}$ & $\begin{array}{l}\text { "...warga memiliki kekayaan } \\
\text { berupa meja, kursi, tenda, } \\
\text { soundsystem, dll yang dibeli } \\
\text { dari kas rukun warga hasil } \\
\text { swakelola sampah..." }\end{array}$ & $\begin{array}{l}\text { “...uang yang masuk kas warga } \\
\text { digunakan untuk pembelian bakteri } \\
\text { aktivasi pengomposan, pemeliharaan } \\
\text { barang, dan untuk kegiatan } \\
\text { masyarakat..." }\end{array}$ \\
\hline
\end{tabular}

Perbandingan Partipasi Warga dalam Pengelolaan Sampah Rumah Tangga. Uraian berikut bertujuan untuk menggambarkan perbedaan tingkat partisipasi masyarakat dalam pengelolaan sampah yang menggunakan dua pendekatan berbeda (Lihat Tabel 7). 
Tabel 7. Perbandingan Partisipasi Masyarakat dalam Pengelolaan Sampah

\begin{tabular}{|c|c|c|c|}
\hline No & Sistem Pengelolaan Sampah yang berlaku & vs & Sistem Pengelolaan Sampah yang direncanakan \\
\hline 1 & 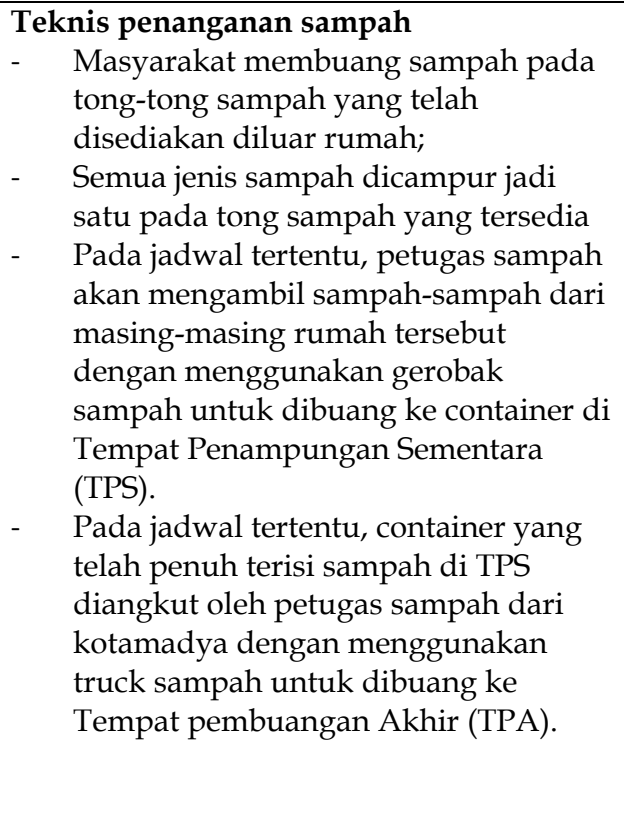 & & $\begin{array}{l}\text { Masyarakat diminta memilah sampah-sampah } \\
\text { yang dihasilkan; Sampah Organik; Sampah } \\
\text { unorganik dan Sampah Bahan Berbahaya dan } \\
\text { Beracun (B3). } \\
\text { Ketiga jenis sampah tersebut tidak dibuang pada } \\
\text { satu tong sampah tetapi dikemas pada } 3 \text { wadah } \\
\text { yang berbeda. Sampah jenis organik diminta } \\
\text { untuk dirajang (ukuran } 1 \mathrm{~cm} \text { ) dan dimasukkan } \\
\text { dalam keranjang kompos; Sampah unorganik } \\
\text { (plastik, kertas kaleng, gelas, besi dll) dikemas } \\
\text { dalam wadah khusus; demikian juga sampah B3 } \\
\text { (baterei, kaleng bekas wadah racun nyamuk, dll). } \\
\text { Pada jadwal tertentu, sampah unorganik dan } \\
\text { sampah B3 yang telah dikumpulkan di masing- } \\
\text { masing rumah akan dikumpulkan atau } \\
\text { diangkutkan petugas khusus untuk ditampung } \\
\text { di Rumah Pilah. } \\
\text { Sampah unorganik kemudian dipilah kembali } \\
\text { dan lebih detail sesuai kemungkinan proses daur } \\
\text { ulang dan pemanfaatan kembali di rumah pilah. }\end{array}$ \\
\hline
\end{tabular}

2 Partisipasi Masyarakat

- Pengelolaan sampah dilakukan oleh para bapak melalui organisasi RT dan RW.

- Telah terdapat kepengurusan yang tetap yang mengelola kegiatan penanganan sampah warga dan melekat pada struktur organisasi warga yakni seksi K3.

- Pada umumnya anggota masyarakat telah membuang sampah pada tempat sampah yang telah disediakan dan telah sepakat membayar iuran pembuangan sampah.

- Pembayaran iuran sampah telah menjadi agenda rutin bulanan dalam pertemuan RT dan RW dari para bapak-bapak.

- Partisipasi warga dalam pengelolaan sampah terletak pada penyiapan tong sampah dan TPS; pembuangan sampah pada tempatnya dan pembayaran iuran pengangkutan sampah.

- Pembahasan pengelolaan sampah diawali dalam pertemuan kelompok Ibu-ibu PKK dan dasawisma; selanjutnya didisseminasikan dalam pertemuan bapak-bapak di tingkat RT dan RW.

- Pengelolaan kegiatan penanganan sampah baru sebatas ujicoba yang juga melekat pada kepengurusan para Ibu PKK.

- Terdapat beberapa ibu rumah tangga yang melakukan pemilahan atas sampah organik, unorganik dan B3. Sampah-sampah organik, khususnya sampah dapur dijadikan kompos dengan menggunakan keranjang kompos. Terdapat 14 orang di wilayah RW 06 dan 26 orang di RW 03 (16 orang ketua dasawisma dan RW; 10 orang anggota dasawisma Delima 5 di RT 01/RW 03). Sejauh ini terdapat 40 orang yang melakukan pengolahan sampah organik menjadi kompos.

- $\quad$ Para ketua dasawisma (15 orang), ibu RT (4 orang) dan RW (1 orang) wilayah RW 03 telah mengumpulkan dan memilah sampah unorganik (terdiri dari aneka kertas, plastik keras dan lunak, kaleng dan botol) dan sampah B3 secara rutin setiap 2 minggu sekali. Sejauh ini hasil pilahan tersebut ditampung dan ditaruh di gudang salah seorang warga RT 01 RW 03.

- Partisipasi masyarakat dalam pengelolaan sampah dengan paradigma yang baru ini antara lain;

- Aktif memilah sampah atas sampah organik, unorganik dan sampah B3

- Kesediaan membeli keranjang kompos secara swadaya (khususnya di 


\begin{tabular}{|c|c|c|c|c|}
\hline No & Sistem Pengelolaan Sampah yang berlaku & vs & Sistem I & ngelolaan Sampah yang direncanakan \\
\hline \multirow[b]{2}{*}{3} & & & ○ & $\begin{array}{l}\text { Dasawisma Delima } 5 \text { RT } 01 \text { RW 03); } \\
\text { Kesediaan melakukan ujicoba } \\
\text { pembuatan kompos di masing-masing } \\
\text { rumah; } \\
\text { Kerelaan menyediakan wadah khusus } \\
\text { untuk menampung sampah unorganik } \\
\text { dan sampah B3; } \\
\text { Ikut aktif memilah sampah unorganik } \\
\text { agar siap untuk didaur ulang dan } \\
\text { digunakan kembali } \\
\text { Kesediaan membentuk dan mengopti- } \\
\text { malkan organisasi warga untuk melaku- } \\
\text { kan kegiatan-kegiatan terkait seperti } \\
\text { pengadaan alat, monitoring dan } \\
\text { pengawasan. }\end{array}$ \\
\hline & $\begin{array}{l}\text { Kelebihan dan kekurangan dari sisi } \\
\text { partisipasi masyarakat } \\
\text { - } \quad \text { Warga diminta untuk menyediakan } \\
\text { satu tempat sampah dan membayar } \\
\text { iuran pengangkutan sampah } \\
\text { - } \quad \text { Sejumlah sumber daya yang dapat } \\
\text { didaur ulang dan digunakan kembali } \\
\text { tidak dimanfaatkan sendiri dan ikut } \\
\text { terbuang seperti plastik, kartoon, } \\
\text { kertas. } \\
\text { Masih membutuhkan biaya untuk } \\
\text { pengangkutan sampah dari rumah } \\
\text { tangga ke TPS. } \\
\text { Kegiatan terbatas pengumpulan, } \\
\text { penarikan dan pembuangan sampah. }\end{array}$ & & \multicolumn{2}{|c|}{$\begin{array}{l}\text { - Warga diminta menyediakan wadah khusus } \\
\text { untuk sampah organik dan melakukan pembuat- } \\
\text { an kompos. Terdapat wadah khusus juga untuk } \\
\text { sampah unorganik dan B3. } \\
\text { - Sejumlah sumber daya yang dapat didaur ulang } \\
\text { dan digunakan kembali (seperti plastik, kartoon, } \\
\text { kertas) dapat dimanfaatkan bersama untuk } \\
\text { kepentingan lingkungan bersama. } \\
\text { Tidak lagi mengeluarkan biaya untuk jasa pe- } \\
\text { ngangkutan sampah, tetapi lebih sebagai pembe- } \\
\text { rian upah untuk suatu usaha bersama. } \\
\text { Kegiatan dapat berkembang menjadi usaha } \\
\text { bersama dengan bentuk kegiatan ikutan lainnya } \\
\text { seperti pembibitan, penghijauan, Toko Tanaman, } \\
\text { dan lain-lain. }\end{array}$} \\
\hline
\end{tabular}

Sumber: Data diolah, 2010

\section{SIMPULAN}

Dengan melakukan peninjauan beberapa aspek di atas, dapat disimpulkan perlunya suatu rencana tindak (action plan) yang meliputi, (1) Melakukan pengenalan karekteristik sampah dan metoda pembuangannya; (2) Merencanakan dan menerapkan pengelolaan persampahan secara terpadu (pengumpulan, pengangkutan, dan pembuangan akhir); (3) Memisahkan peran pengaturan dan pengawasan dari lembaga yang ada dengan fungsi operator pemberi layanan, agar lebih tegas dalam melaksanakan reward $\mathcal{E}$ punishment dalam pelayanan, (4) Menggalakkan program Reduce, Reuse dan Recycle (3 R) agar dapat tercapai program zero waste pada masa mendatang, (5) Melakukan pembaharuan struktur tarif dengan menerapkan prinsip pemulihan biaya (full cost recovery) melalui kemungkinan penerapan tarif progresif, dan mengkaji kemungkinan penerapan struktur tarif yang berbeda bagi setiap tipe pelanggan; (6) Mengembangkan teknologi pengelolaan sampah yang lebih bersahabat dengan lingkungan dan memberikan nilai tambah ekonomi bagi bahan buangan.

Pilot project Pengelolaan Sampah Rumah Tangga Berbasis Masyarakat di Sambiroto Semarang, telah berhasil dilaksanakan dengan prinsip 3R (Reduce, Reuse, Recycle) melalui proses pemilahan sampah. Model yang diterapkan mampu mereduksi volume sampah yang dibuang hingga 70 persen. 
Sistem pengelolaan sampah rumah tangga berbasis masyarakat dengan prinsip $3 \mathrm{R}$ melalui kegiatan pemilahan sampah merupakan solusi paradigmatik, yaitu solusi dari paradigma cara mengelola sampah. Dari paradigma "membuang sampah" yang dalam prakteknya hanya memindahan sampah, menjadi "mengelola sampah" dalam arti memilah untuk dimanfaatkan yang pada prakteknya dapat mereduksi secara signifikan timbulan sampah yang dibuang.

Problematika utama dari penerapan model ini adalah pada soal bagaimana merubah paradigma dari membuang sampah menjadi memanfaatkan sampah. Peran pengurus RT/RW sangat besar dalam membantu mewujudkan terlaksananya program dan menjembatani komunikasi antara pemerintah daerah dengan masyarakat.

Saran. Penanganan sampah merupakan bagian dari tanggung jawab masyarakat dan terletak pada komitmen pemerintah kota atau kabupaten. Adapun konsep dasar penanganan sampah mencakup dari aspek:

(1) Aspek Teknis/Fisik. Penetapan standar pelayanan, sehingga adanya dukungan dan peran serta masyarakat; Pemilihan teknologi tepat guna, mudah dilakukan pemanfaatan dan bernilai ekonomis; Perencanaan prasarana fisik sesuai dengan master kota yang berwawasan lingkungan.

(2) Aspek Pengelolaan. Komitmen dari pemerintah kota atau kabupaten dalam pengelolaan; Pembinaan mekanisme dan pengelolaan dengan konsep manajemen yang baik; Penetapan organisasi dan prosedur; Pembinaan tenaga kerja yang terampil dan produktif; Penggalian sumber dana dan pembinaan system pembiayaan.

(3) Aspek Sosial. Penyuluhan pada masyarakat yang terprogram dengan baik dan terus menerus; Penciptaan iklim pengelolaan kebersihan yang terpadu dengan kegiatan masyarakat; Peran serta dan dukungan masyarakat.

(4) Aspek Pengaturan Hukum. Melengkapi peraturan yang dibutuhkan sehingga dapat dijadikan dasar hukum yang tegas; Enforcement dari peraturan.

(5) Aspek Swadaya Masyarakat.Pembinaan sektor formal instansi pemerintah dan swasta ber- peran dalam pengelolaan sampah; Pembinaan sector informasi, karang taruna dan organisasi masyarakat.

(6) Aspek Lingkungan. Pembinaan kesehatan masyarakat, dengan melakukan penyuluhan; Penyehatan lingkungan pemukiman, perbaikan dan peningkatan sarana.

Agar peran serta masyarakat dapat optimal hendaknya masyarakat telah mengelola sampah di rumah masing-masing dengan cara mengemas sampah dan memisahkan antara sampah basah dan kering atau sampah organik dan anorganik, sehingga petugas pengumpul dari segi waktu lebih efisien.

Agar pelaksanaan pengelolaan sampah lebih efisien maka dilakukan kegiatan seperti: (a) Kegiatan subsistem pengumpulan, hendaknya mengaktifkan kembali peran RT dengan memakai mekanisme swadaya masyarakat; (b) Subsistem angkut, kegiatan yang berjalan sekarang melalui pihak swasta dapat dipetahankan; (c) Subsistem pembuangan akhir, dapat diserahkan kepada pihak swasta atas dasar perhitungan nilai ekonomis; (d) Pada penataan dan penentuan lahan TPA hendaknya dalam pembebasan bukan hanya sesuai dengan kebutuhan. Pembuangan sampah jangka pendek tetapi pembebasan memperhatikan aspek akan bermunculannya pemukiman baru sehingga TPA menjadi masalah dengan masyarakat yang ada di sekitarnya, metode pembuangan yang baik adalah sanitary landfill; (e) Hendaknya para pengusaha yang memusnahkan sampah dari produk yang sudah kadarluarsa lebih memikirkan akibat dari produk yang dibuang ke TPA apabila diambil oleh pemulung dan dijual kepada oknum digantie kemasan sehingga merugikan terhadap kesehatan masyarakat

\section{Ucapan Terima Kasih}

Terima kasih disampaikan kepada tim peneliti lain yang telah meminjamkan data, dan kolega yang telah berkontribusi dalam memberikan komentar atas tulisan ini (Drs. Bagio Mudakir, MSP; Drs. Mulyo Hendarto, MSP; Prof. Dr. Waridin, MS; Prof. Dr. Indah Susilowati, M.Sc), Ir. Syafrudin, CES). 


\section{DAFTAR PUSTAKA}

Alexander Abe. 2001. Perencanaan Daerah Memperkuat Prakarsa Rakyat dalam Otonomi Daerah. Yogyakarta: Lapera Pustaka Utama.

Anonim, 2008. Olah Sampah, http://www.pus dakota, Jakarta.

Departemen Pekerjaan Umum. 2006. Permen PU nomor: 21/PRT/M/2006 tentang Kebijakan dan Strategi Nasional Pengembangan Sistem Pengelolaan Persampahan (KSNP-SPP), Jakarta

Emil, Salim. 1990. Kumpulan Makalah Perubahan Lingkungan Global dan Kerjasama Internasional. Bogor: IPB.

Enviromental Service Program (ESP) DKI. 2006. Modul Pelatihan Pengelolaan Sampah Berbasis Masyarakat.

Faizah. 2008. Pengelolaan Sampah Rumah Tangga Berbasis Masyarakat (Studi Kasus di Kota Yogyakarta). Tesis Magister Ilmu Lingkungan. Universitas Diponegoro. Semarang

Fauzi, A. 2004. Ekonomi Sumber Daya Alam dan Lingkungan, Teori dan Aplikas. Jakarta: Gramedia Pustaka Utama.

Gelbert, M., et. al. 1996. Konsep Pendidikan Lingkungan Hidup dan "Wall Chart", Buku Panduan Pendidikan Lingkungan Hidup, PPPGT/VEDC, Malang.

Hadi, Sudharto P. 2005. Dimensi Lingkungan Perencanaan Pembangunan. Yogyakarta: Gadjah Mada University Press.

Hadi, Sudharto P., 2004. Sindrom Sampah, Kompas 7 Desember 2008, Jakarta.

Hikmat, Harry. 2001. Strategi Pemberdayaan Masyarakat. Bandung: Humaniora.

Iqbal, Muhammad. 2008. Konstelasi Institusi Pemerintah dan Lembaga Swadaya Masyarakat dalam Program Pidra. Jurnal Ekonomi Pembangunan FE UMS. Vol. 9, No.1, Juni 2008, hal. 28-45. Surakarta: BPPE UMS.
Irawan, Agus. 2009. Pengelolaan Sampah Kota. www.suara merdeka.com

Kementerian Lingkungan Hidup. 1997. UndangUndang RI Nomor 23 Tahun 1997, tentang Pengelolaan Lingkungan Hidup, Jakarta

Komang Ayu, Ni. 2009. Peran Serta Masyarakat dalam Pengelolaan Sampah Rumah Tangga (Studi Kasus di Sampangan dan Jomblang, Kota Semarang). Tesis Magister Ilmu Lingkungan. Universitas Diponegoro. Semarang.

Kompas, 10 Januari 2004. Sampah dan Pemerintah, diakses dari http://www.kompas. com.

Kompas, 13 Agustus 2003. Sampah, Cermin Wajah Perkotaan, diakses dari http:// www.kompas.com.

Kormondy, EJ. 1969. Concepts of Ecoroglt. New Jersey: Prentice-Hall Inc.

Menteri Pekerjaan Umum Republik Indonesia, 2006, Peraturan Menteri Pekerjaan Umum Nomor 21/PRT/M/2006 tentang Kebijakan dan Strategi Nasional Pengembangan Sistem Pengelolaan Persampahan, Jakarta.

Moelyarto. 1996. Pemberdayaan Masyarakat Tertinggal. Bandung: Humaniora.

Purdiyanto. 2009. Peran Serta Masyarakat dalam Penanganan Sampah untuk Meningkatkan Mutu Lingkungan. Laporan Penelitian Kesehatan Lingkungan dan Kerja.

Rahadyan dan Widagdo A.S. 2002. Peningkatan Pengelolaaan Persampahan Perkotaan Melalui Pengembangan Daur Ulang. Materi Lokakarya 2 Pengelolaan Persampahan di Provinsi DKI Jakarta.

Salim, Emil. 23 Juni, 2005. Hidup Dari Sampah, Belajar dari Prof Hasan Poerbo. Harian Kompas.

http://hasanpoerbo.blogspot.com/2006/04/hi dup-dari-sampah-belajar-dari-prof.html [14 Maret 2010].

Slamet, Y. 2002. Konsep-konsep Dasar Partisipasi Sosial, PAU-SS UGM Yogyakarta Setyawati, D. 2008. Arahan Pemanfaatan Kem- 
bali Tempat Pembuangan Akhir (TPA) Sampah. Semarang: Universitas Diponegoro.

Surbakti, Sriliani. 2009. Potensi Pengelolaan Sampah Menuju Zero Waste yang Berbasis Masyarakat di Kecamatan Kedungkandang Kota Malang. Laporan Penelitian Institut Teknologi Surabaya.

Surochiem. 2001. Dimensi-dimensi penting Monitoring Pelaksanaan Program Pemberdayaan dan Partisipasi pada Masyarakat Pesisir. Jurnal Neptunus Vol.8, No.1 Maret 2001 50-56, Surabaya.

Suryanto, Ari, dkk. 2005. Kajian Potensi Ekonomis dengan Penerapan $3 R$ pada Pengelolaan Sampah Rumah Tangga di Kota Depok

Susilowati, Indah, et al. 2005. Pengembangan Model Pemberdayaan Masyarakat Pesisir Dalam Mendukung Ketahanan Pangan di Kabupaten dan Kota Pekalongan. Laporan Penelitian RUKK Tahun II, Universitas Diponegoro, Semarang.

Susilowati, Indah, et. al. 2004, Pengembangan Model Pemberdayaan Masyarakat Pesisir dalam Mendukung Ketahanan Pangan di Kabupaten dan Kota Pekalongan. Laporan Penelitian RUKK Tahun I, Universitas Di- ponegoro, Semarang.

Syafrudin. 2004. Model Pengelolaan Sampah Berbasis Masyarakat (Kajian Awal Untuk Kasus Kota Semarang), Makalah pada Diskusi Interaktif: Pengelolaan Sampah Perkotaan secara Terpadu, Program Magister Ilmu Lingkungan UNDIP.

Togarsilaban. 2007. Keranjang Ajaib Takakura, http://www.togarsilaban, jurnal, Jakarta.

Tuti Kustiah. 2005. Kajian Kebijakan Pengelolaan Sanitasi Berbasis Masyarakat, Pusat Penelitian dan Pengembangan Permukiman, Badan Penelitian dan Pengembangan Departemen Pekerjaan Umum, Bandung

Umar, Ibnu. 2009. Pengelolaan Sampah Secara Terpadu di Wilayah Perkotaan. Jurnal Lingkungan Hidup.

Universitas Diponegoro, 2007. Community Development. Lembaga Penelitian Undip. Semarang.

Wibowo, A. dan Djajawinata D.T. 2004. Penanganan Sampah Perkotaan Terpadu. Diakses tanggal 4 Desember 2006 pada halaman www.kkpi.go.id. 


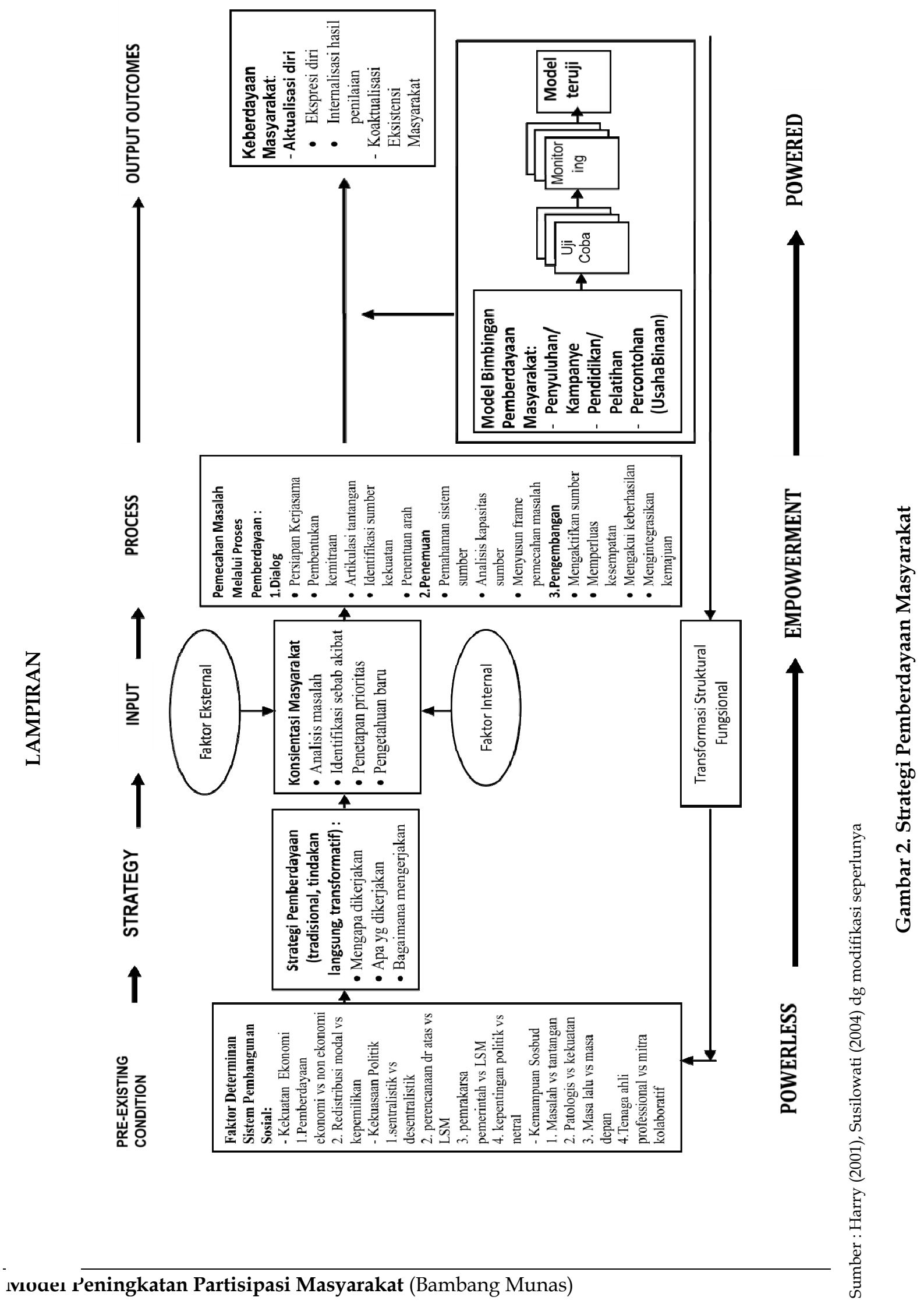




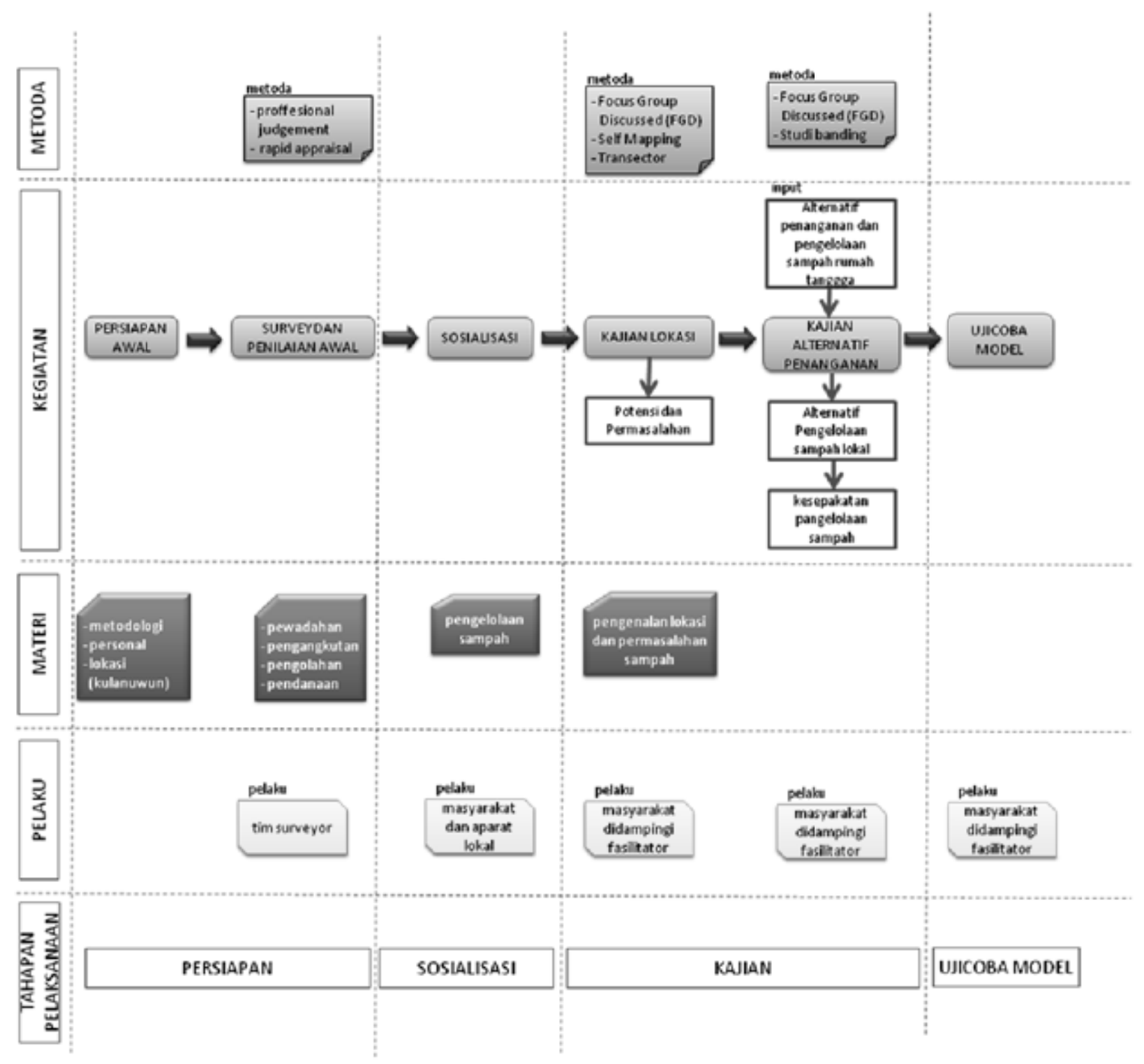

Gambar 4. Diagram Pelaksanaan Peningkatan Partisipasi Masyarakat dan Penguatan Sinergi dalam Pengelolaan Sampah Perkotaan di Kelurahan Sambiroto, Kecamatan Tembalang, Kota Semarang 